\title{
Toward an Ideal Relational Ethic: Re-thinking university-community engagement
}

\author{
SteVE GARLICK AND Victoria J. PALMER
}

$\mathrm{T}$ his article argues for the importance of developing a relational ethic to guide university-community engagement practices and processes. Our objective is to demonstrate that ethical 'engagement bridges' can be formed to link higher education institutions (HEIs), human capital at the community level, and the important global questions of our day that resonate with regional communities. Taking centre place in this triad is the notion of being-for, an ideal form of togetherness put forward by Zygmunt Bauman (1995) in his early work on globalisation and post-modernity. Being-for is presented in this article as a moral aspiration that, if embraced, can tie together engagement scholarship with the development of enterprising human capital, and result in ethical outcomes in the universitycommunity engagement arena.

Our premise is that modern day tertiary education institutions

Gateways: International Journal of Community Research and Engagement No 1 (2008): 73-89

(c) UTSePress and the authors 
are based on a neo-liberal funding paradigm with conditional obligations. Funding conditionality is not an issue unique to these institutions, but it has particular relevance here if we are to critically consider how engagement between university and community can rebuild fragmented social ties and support economic development and growth. This is because university-community engagement exists within a context of governance (Boydell et al. 2008), where the conditions and rules that are set down by funding bodies are sometimes at odds with and override larger ethical obligations and goals. We want to consider how, within the ethical relation of beingfor, we can find a space to keep the moral agenda alive and ensure ethical consequences for regions and the people within them. This means using being-for as a platform to explore the spatially-relevant ethics, or 'sp-ethics', of university-community engagement.

\section{FORMS OF TOGETHERNESS AND ENGAGEMENT}

Bauman (1995) proposed that contemporary global conditions and social relations are characterised by three different forms of togetherness: being-aside, being-with and being-for. The ideal, being-for, provides the basis from which to conceptualise an alternative to contemporary neo-liberal conditions currently dominant in tertiary institutions. Neo-liberalism fosters and favours connections that are fragmentary, momentary and occasional. The conditions are characterised by values of competition, efficiency and individualism. Such relationships respond to needs as they arise rather than being relationships that are formed longitudinally, according to mutually shared goals. The neo-liberal vision is strongly embedded in many public and private institutions and it is one that is antithetical to building a common good that emphasises fairness, justice and equality. It creates 'the imposition of hard and fast lines around us; to make of the individual an atom, a being-for-itself, autonomous, selfinterested and introspective' (Davidson 2000, p. 642). Under neoliberal conditions we become isolated, separated and at a distance from each other; such conditions do not foster an ideal form of togetherness that can take us forward to the development of ethical communities.

Neo-liberalism, its conditions and subsequent non-relations, thus require critique in the context of developing stronger and better university-community engagement processes and practices. Left alone, these relations err toward what Bauman (1995) called relations 
of being-aside rather than being-for. Being-aside is described by Bauman as a relationship where others are not recognised as entities that matter but rather are seen as being co-present. In being-aside, resources and physical space are shared but there is no recognition of others as being 'person-like'. From this setting of being-aside, copresence moves toward being-with, where there is a selected recognition of others. In the being-with relation other people move into the realm of persons, but not in an entirely certain manner, and only to the degree that they are necessary to the encounter. Bauman (1995) suggests that being-with is still a mis-meeting of incomplete and deficient selves as a result of this. The ideal relation is being-for where the full ingredients of the person are seen as precious and this is applied in a non-selective manner to all beings regardless of their status.

Bauman (1995, p. 52) is careful to explain that 'none of the known forms of togetherness privileges the being-for relation, but none of them ward it off either'. However, being-aside is an on-the-side encounter that does not hold the moral recognition of others as important and being-with seems much more characteristic of selfinterested relationships. Subsequently, it seems possible to suggest that having the aspiration of being-for will result in its formation much more so than not having it. It is in this respect that we believe Bauman's (1995) ideal form of togetherness provides a basis from which to develop processes and practices for university-community engagement.

\section{ENGAGEMENT AND THE SP-ETHICS OF IT ALL}

If we recall the concept of being-for as an 'engagement bridge', then its realisation may be achieved through the ways in which it informs the creation of human capital - that is, graduates with creative, enterprising and engaged skills - and where the needs of people within their communities are met through the acts and practices of engagement between university and community. This notion of being-for, as a link, is based on the view that university-community engagement has a moral purpose and explicit agenda to deploy enterprising human capital formation as an intentional strategy to achieve ethical outcomes. These ethical outcomes need to be formed around relationships between persons and not entities (such as corporations and government and non-government institutions, 
where entity-centric, rather than individual views matter). Such relationships need also to be predicated on spatially-relevant ethical values, or sp-ethics.

Sp-ethics refers to the combined interaction of values and principles relevant to local places, the fostering of enterprising human capital based on local needs and identity, and geographicallyspecific concerns. Sp-ethics evolves through the process and practices of people engaging together within the community, where learning is seen as a two-way street, and the formation of tacit knowledge is valued as equally as that of explicit knowledge (Boydell et al. 2008). Sp-ethics focuses on the things of shared importance to members in that location, with the proviso of needing to be cautious of falling into the traps of exclusive localism. To articulate sp-ethics one needs to have the ideal form of togetherness being-for at the centre of all engagement processes and practices - that is, being-for is the premise for universities to commit to sp-ethics. Sp-ethics embodies the sense of 'a community woven together from sharing and mutual care' (Bauman 2001, p. 150). More importantly, it acknowledges that the experience of space is fundamental to our identity (Davidson 2000).

According to Bauman, modern institutions, like modernity itself, have become liquid. Social structures have weakened and their disappearance heralds an era of short-term projects and episodes which are no longer characterised as sequential forms of progress or development (Bauman 2007). Knowledge in this setting travels through information highways to a plethora of diverse destinations and circumstances, and what was once distant is now much more familiar and closer than before. The idea that community and university engagement can be built from a one-size-fits-all format, as in a central agency policy prescription, does not work in this globalised context.

This means that community engagement principles and processes, as well as the role of the university in developing enterprising human capital, need to be considered within a spatial context. This spatial context includes geographical location, physical environments, the built-environment, the natural environment, and human and non-human beings within this. This sees spatiality as a commonly shared and commonly shaped good that can move us away from seeing identity as a privatised and individual affair increasingly defined by 'social standing and the purchasing of statusgiving positional goods' (Rutherford 2007, p. 19). 
Rutherford (2007) also suggests that in our contemporary world when we try to grasp the meaning of society, it often escapes us like water. Quoting Bauman, he discusses how neo-liberal society has become a place of:

[i]ncreasingly individualised individuals, [a place] which cannot easily hold its shape - it neither fixes nor binds time and space. Fluids flow and yield to the slightest pressure. They drip, flow, gush, swirl, disperse into particles, gather into a flood (Rutherford 2007, p. 9).

The slippery nature of human relations does need to be acknowledged in the formation of community engagement strategies and planning. Communities are not predictable entities upon which formulaic models can be overlaid. Boydell et al. (2008, p. 211) argue that knowledge is dynamic, and its articulation can often become static and mask what is tacitly known. In this liquid world, attention must be directed at fostering and anchoring enterprising human capital in ways that respond to local community needs and conditions.

\section{THE ROLE OF THE UNIVERSITY}

According to Boyer (1996), Dewey (1956; 1961), Benson and Harkavy (2002), Garlick and Palmer (2007) and others, universities are not simply 'drive-through mobility factories' where students privately gain something to help them fall into a future determined by others. Universities have 'a larger purpose, a larger sense of mission, a larger clarity of direction in the national life' (Boyer 1996, p. 20). This is the traditional understanding of universities as being places that form ethical citizenry and communities that have a moral character and future built around new knowledge. However, funding pressures and the push to be globally competitive have put universities at risk of losing this sense of an ethical citizenry and the shaping of the common good.

The role of universities in encouraging citizen learning and knowledge acquisition meant for Dewey that participation in these processes, '[was] to make the work of the chaotic [city] metropolis intelligible to its most disadvantaged citizens' (Addams cited in Bellah et al. 1992, p. 152). In this respect, one of the goals of education is for it to be transformative and deliberative, and in this somewhat 
confusing global age to make life intelligible to all people regardless of group membership. This means having a strong moral and ethical purpose as a guiding vision that goes beyond individual gain and profit making. Moreover, the non-selective nature of being-for relations needs to be embraced over the selective and exclusionary ones of being-with. When the focus of outcomes is without regard to spatial concerns of regions and communities, then the trap of selective relationships is ever present. Universities have been forced to adopt being-with relations in the neo-liberal climate. The introduction of up-front fees and the limits this has placed on all people having access to educational opportunities is a case in point.

This is not to say that the slippery, liquid nature of life can be captured and fully understood by universities and used to develop ethical engagement, but forms of togetherness that are premised on open enquiry and critical questioning (learning) are essential. In view of this, one of the primary principles that ought to underpin university and community engagement, then, is that community participation be oriented toward the creation of a good society, or in other words, a commonly shared good. Such learning ought not to be exclusive and out of reach of those at the margins of society.

Universities need to reach out to the community and they need to do so in ways that include a perspective of being-for, rather than one of private institutional advantage. In other words, universities in the first instance should seek to create graduates (human capital) with the best knowledge and skills that can contribute to assisting community priorities in a globalising world, rather than simply being focused on input or student numbers. This is a significant public good role for the university engaging with its community. As well, the scholarship of university and regional community engagement should be premised on concepts of discovery, integration, knowledge sharing, and on-the-ground application (Boyer 1996). This means understanding individual values and communal identities shaped by local circumstances and context, and acknowledging the tacit knowledge held within communities to harness and identify their enterprising human capital.

\section{UNIVERSITIES AND THEIR RELATIONSHIP WITH 'COMMON GOOD'}

Most universities whether they are publicly or privately funded show 
characteristics of being-with relations above and beyond those of being-aside in the neo-liberal context. However, as institutions oriented toward serving and shaping the public good, universities must always be aware of the inherent risks of the fragmentary and momentary nature of neo-liberal encounters. If they are not, then they risk falling into the traps of inconsequential resource sharing and always being just to one side of communities.

As private enterprise comes to have a vested interest in the activities of public education institutions it is important that these issues are ethically critiqued. This means, for example, asking whether the conditions associated with the funding that universities do receive are focused on improving community outcomes. It means looking at engagement programs through the lens of sp-ethics and setting down core criterion and questions for assessment, such as asking if spatially-relevant ethical needs, identities and values are being taken into account. How much has the university harnessed the enterprising human capital and generated the conditions for this to flow outward from the engagement process?

Claims that 'universities are not public goods that require government subsidies ... [and that] higher education can be financed privately' (Schwartz 2006, p. 3) risk eroding relations between universities and their communities. Those at the margins, those in the middle, find it harder and harder to engage with public education, which fosters entity-like rather than person-like recognition. The more that a competitive, business logic underpins the conditions of university funding, the more that university engagement with its student and community populace begins to take on the appearance of a common utilitarian agenda which disregards spatial and human uniqueness, and a sense of place. Considerations of the majority reign and in this climate universities become tied to accountability measures and project development requirements that reflect the needs of funding bodies over the needs of the community. In this context, community engagement risks being a top-down endeavour applied to settings and locations, instead of evolving in a bottom-up manner. Scholarship loses its connectivity to the places within which it occurs and we ask in this environment, 'do universities know what the common, public or shared goods of their regional and local communities are'?

In this neo-liberal environment where the values of competition, 
efficiency and productivity dominate, universities fail the Boyer (1996) test of engaging with the public good. Indeed, we propose that if sp-ethics are taken into account universities now need to engage with a common good that can incorporate all beings and forms of life, not just humanly defined ones. At present, forms of togetherness are fragmented in terms of the connection between scholarship, place and ethical outcomes. The difficulty of being-aside and being-with relations is that people in communities are not given the opportunity to contribute in a creative and engaged way to a common good. Or rather, where they are given this opportunity, the objectives have already been set by somebody from outside of the location and without mutual conversation. By proposing that Bauman's (1995) conception of the ideal ethical relation ought to underpin scholarship of community engagement, we do not intend to reduce Bauman's (1995) concept of ethical relations to an economic one. The goal instead is to acknowledge that universities need to foster enterprising human capital that can contribute to community development whatever their needs may be.

Communities are not value-free places where institutions such as universities can locate themselves and assume students are naturally part of ethical communities that provide a haven for certainty, security and safety (Bauman 2001). Ethical communities must be fostered, worked at, critically engaged with and they are certainly not places of funding conditionality (Cooper 1997; Palmer 2006). Palmer's (2008) recent work also illustrates the problematic of value convergence when private and public enterprises are tied together with conditional funding obligations through partnership arrangements. This places limits on how far educational institutions can maintain a commitment to a sense of a shared common good when constrained by funding conditions.

Contrary to Schwartz's vision of ethical communities largely built around economics, Cooper (1997, p. 11) articulates that ethical communities are 'multi-logical (in that they incorporate more than just one logic, which in the neo-liberal world is an economic logic), they are dialogical (conversation based and relationally formed), they are heterogeneous, they do not have an all encompassing tradition, and they are reflective, analytic, involved and open'. This is contrasted for Cooper (1997, p. 10) with moral communities where 'norms are imposed, codes for behaviour are given based on preexisting traditions, law and order is imposed to deal with chaos, 
homogeneity is favoured, and communities are authoritative, devolved, closed and bounded'. For us, Schwartz's vision of the exclusively privately funded university is a moral community; one where the opportunity for universities to contribute to the wider common good and to the development of enterprising human capital is closed off.

Universities were once considered places where contribution to a commonly shared public good was integral to scholarship. So the idea of a social practice (Isaacs 1998), such as weaving ethical values into the creation of human or knowledge capital, is fitting to understanding concepts of scholarship of engagement (Boyer 1996; Benson and Harkavy 2002). Isaacs (1998, p. 5) posits that:

[s]ocial practices are not natural phenomena independent of persons ... social practices are both constructed by, and constituted by, persons ... in social practices persons enter into a collaborative engagement to achieve a common goal, or to promote a desired good, which would be unreasonable at the purely individual level.

Indeed, Schwartz (2006, p. 4) too, in spite of claiming support for private funding of universities, supports the notion that education ought to have a purpose and that the purpose is to develop ethical behaviour. To provide a 'basic sense of ethics', as Schwartz (2006, p. 4) contends, requires more than an involvement and participation that simply generates economics. Moreover, it means having an appreciation that ethical purpose and behaviour might be placed somewhat in tension with sole private funding of public institutions. If funding prescribes certain rules that must be adhered to and if that funding disregards the sp-ethics of locales, then the ethical is at risk. Universities need to be places that not only foster creativity in their human capital - a conscience of being in a social and economic world - but should also be places that encourage a purpose for doing (enterprising). Knowledge generation ought to be seen as a social practice that provides the basis for ethical engagement to proceed; and that the being should not be placed at risk by the doing.

Our proposition is that universities can in fact foster being-for relations in their communities through their human capital creation tasks (that is, instilling creativity, enterprising and community engagement skills in their graduates). This is an intentional move 
away from capital being seen purely in private economic terms, to being seen in a socially constituted context. In recent work Bauman (2007, p. 82) has noted that 'one of the most bewildering paradoxes revealed in our time is that on the fast globalizing planet politics tends to be passionately and self-consciously local'. While being-for represents the embodiment of a commitment to ethical relations that transcends local place and space, the importance of local identities in engagement practices and processes cannot be ignored. Indeed to acknowledge identity means incorporating the spatial nature within which it forms. This will undoubtedly mean taking into account a range of issues that are important in that area such as environmental or socio-political contingencies. These factors and considerations will become all the more important as HEIs regionalise and engage with communities with diverse needs and abilities.

Thus, higher education institutions are central to a particular vision of a public good that can be fostered in communities (Boyer 1996; Isaacs 1998; Benson and Harkavy 2002; and Garlick \& Palmer 2007). However, it is a vision that Sunderland \& Graham (2006) assert has been eroded by economic rationalism. Because economic rationalism is dependent on relations which are certainly aside and often with, universities that incorporate conditional funding arrangements into their education agendas will not be able to articulate 'a vision of what they are trying to achieve for society, or to live up to it' (Schwartz 2006, p. 4); something more than this will be needed.

\section{ENTERPRISING HUMAN CAPITAL FORMATION}

In their study of the drivers of regional growth in Australia between 1984 and 2002, Garlick Plummer and Taylor (2007) found, using mixed quantitative and qualitative analysis across ninety four regions, that human capital was the most significant determinant, followed by technological change and industry specialisation. Institutional intervention (mostly in the form of government assistance measures) was a negative driver of regional economic growth outcomes. This suggests a significant HEI role not only on the supply side through the provision of ethically aware knowledge workers, but also in stimulating greater regional demand through engagement across education and productive sectors. According to Garlick et al. (2007, p. 33), the human capital contribution to growth in regional communities comes via the process of 'enterprising', 
where human capital is fostered and focused on achieving outcomes of regional community benefit. In this sense, enterprising human capital is about education rather than training. It is about equipping individuals, free of entity connections, with an understanding of the economies and societies they are a part of, the processes of change that run through them, and the ways in which they might effect change. Training, on the other hand, equips individuals for what is known now and for supporting the 'winners' that others have chosen. Training is not about new directions, ideas and opportunities.

'Enterprising' human capital in the regional context involves having the skills to take an idea or opportunity and, with others, turn it into an on-the-ground outcome that addresses an important community or spatial concern. The case of locally developed cooperative businesses - those that respond directly to a community need, where membership is formed via ongoing commitment to shared values, and have declared principles that include ongoing education - is a good example of this. Enterprising human capital is relational with other people and not solely based on entities.

Garlick (2007) has also found that there is a growing divergence in both the stock and flow of human capital between a select few high growth metropolitan regions and a much larger number of relatively low growth non-metropolitan regions. Human capital, much like Bauman's (2007) notion of liquid modernity, risks flowing downstream from low growth non-metropolitan regions to high growth metropolitan regions. The task of the university and its engagement with its community is to address this spatial imbalance, and the ethical implications of it. This will mean engaging in locally defined activities and needs.

Universities are seen as having a dual role in contributing to stronger human capital outcomes and ethical perspectives in the regional community. On the supply-side they can through their teaching and learning programmes embed enterprising as well as creative and engagement skills that have an ethical dimension and a connection to the needs of the regional community. This is the embodiment of a scholarship of engagement by its teaching and research staff. On the demand-side they can stimulate greater university entry in the community by creating pathways for those to move through and up. That is, practising university-community engagement from the basis and perspective of being-for relations that 
are non-selective.

Garlick et al. (2006) have identified some of the common features of many regional communities outside key global growth centres. First, high levels of human capital leak out through a brain drain of university-educated graduates and through the daily commuting of professional and senior management to larger centres. Second, there is an underutilization of human capital through its underemployment in basic service skills and an underutilization of the skills of the productive ageing demographic cohort. And third, there is a failure to reach out to and include those at the margins of the education system. The mix of these impacts will be different in diverse regional communities and it is important for universities to identify the human capital circumstances and needs in the communities of which they are a part.

Universities can design and deliver programs that seek to overcome this low equilibrium picture where human capital is inefficiently used. It is in fact their ethical imperative to do so as leakages and barriers to the progression of human capital to higher levels limits the extent to which a community can ethically address the big issues of the world that resonate locally. This will mean developing educational programs that are relevant to communities and regions so that enterprising human capital becomes a strategy for achieving ethical engagement. If universities take up this challenge there is greater potential for ethical communities to evolve.

\section{THE ETHICAL COMMUNITY}

For Bauman (2001), striving for the elusive 'community' in a globalising world of individuals is not about obtaining security, freedom and homogeneity of cultures and views by setting in place borders. In fact, Bauman (2001) has suggested that 'community' as a concept is an imagined ideal, one that we desperately long for and to which we hope to return but never have entirely within our reach. Borders are by nature fluid and influenced by our perceptions and relatedness with each other in the world; they are only imagined in so far as we place limits on them. Ethical communities are possible when communities have equality of access, achieved not through regulation but by local enterprise.

Of course, ethical communities require recognition that distinctly moral fields already exist in geographical locations and some of them 
will need to be critiqued. These moral fields are 'expressed in a spatiotemporal metaphorics, a discourse of relativity, proximity, dimensionality, distances, volumes and velocity and so on' (Smith 2001, p. 151). We can detect the proximity of relations in communities, the value dimensions which make people close or far apart, and the volume and velocity at which community is changing. While Smith (2001) explains spatiality metaphorically, he is quick to dispel any notion that moral spaces are meant only metaphorically. Indeed, Bauman's (1995) concepts of forms of togetherness can illustrate proximity, distances, dimensionality and recognition between people in their communities.

Moral spaces are socially produced and constituted realities that require ongoing conversations based on mutual encounters to identify the values and principles at play. These encounters are sometimes not easily achieved, but the commitment to such dialogue must be maintained. Bauman argues:

If there is to be a community in the world of individuals, it can only be (and it needs to be) a community woven together from sharing and mutual care; a community of concern and responsibility for the equal right to be human and the equal ability to act on that right (2001, pp. 149150).

This means that in our communities we need to imagine ourselves engaged in relationships with others and to think about other beings as equally entitled to just treatment and access to resources as we ourselves are. The tendency here would be to see our argument as purely a deontological one and for our proposition for being-for to be applied regardless of the consequences. If the application of being-for means that there is a reduction in the inequities of access to education or that there is less injustice because of selective entry requirements, then this achieves our desired ethical end. Consequential normative ethics, like utilitarianism which is focused on the greatest good for the greatest number, ignores the reality that not everyone is recognised as being a part of the greater good and most certainly, not all non-human beings are considered a part of it. In reality, it is both the consequences of our actions that benefit the common good and our intentions to be ethical that matter. Without the moral aspirations that deontological, or duty-based ethics offers, we are left devoid of 
principles and values to follow in process and practice.

Bauman (2007) notes the trend to community homogeneity and a distrust of diversity and 'otherness' in a liquid neo-liberal world, giving rise to 'mixophobia' in communities. In such fragmented places all that can be expected are being-aside and being-with forms of togetherness (Bauman 1995). Such forms of togetherness are limited to episodic and usually competitive encounters of individuals, where they are viewed more as objects or entities than as humans with respected intrinsic qualities.

The ethical community neatly brings together the two ideas of a being-for ethic and enterprising human capital that we suggest is a way forward for universities to engage with their communities via the development of sp-ethics. The question arises as to whether there might exist a kind of spatial context for ethics where local circumstances and needs provide the frame for the 'sharing' and 'mutual care', not only from an ideas perspective (creativity), but from a doing (enterprising) perspective. How the transformation from creative capital to enterprising capital is achieved and supported by universities in their engagement with regions and communities is a critical ethical question to be addressed in future research and theorising.

\section{CONCLUSION}

Bauman (1995) proposes that being-for can arise from the act of transcendence of being-with relations. In a sense, we take this to mean that commitment to the aspiration can translate to the act of transcendence itself and produce ethical outcomes. For us, this does not mean that moral and ethical purpose exists in a transcendental state, located nowhere but so obviously somewhere. Rather, universities need to articulate clear visions and ethical purpose for their engagement processes and practices, and there needs to be a desire to attain ethical engagement that can result in ethical communities, particularly in a context where neo-liberal moral communities reign supreme. Being-for is transmitted through social practices where enterprising action transforms creative capital into beneficial and ethical social, economic and environmental outcomes, with potential far beyond that intended at the outset. While beingaside and being-with do not, as Bauman (1995) articulates, close off the possibility of being-for, it is fairly clear from our analysis that these forms of togetherness are unlikely to facilitate the aspiration for 
ethical engagement.

University and community engagement needs to be premised on ethical intentions. Being-for is our proposed conceptual bridge between scholarship of engagement intentions, developing enterprising human capital and the translation of these to ethical outcomes. This premise forms the basis of teachers and researchers within universities embodying an ethics of engagement. A failure to engage in these ways ensures universities and their communities do not tackle in an ethical way the big issues of the world that resonate locally. They thus fail in their responsibility to contribute to, and shape, a shared and committed common good.

\section{REFERENCES}

Bauman, Z 1995, Life in fragments: Essays in postmodern morality, Blackwell Publishers, Oxford.

Bauman, Z 2001, Community: Seeking safety in an insecure world, Polity Press, Cambridge.

Bauman, Z 2007, Liquid times: Living in an age of uncertainty, Polity Press, Cambridge.

Bellah, R, Madsen, R, Sullivan, WM, Swidler, A \& Tipton, S 1991, The good society, Alfred A. Knopf, New York.

Benson, L \& Harkavy, I 2002, Truly engaged and truly democratic cosmopolitan civic universities, community schools, and development of the democratic good society in the $21^{\text {st }}$ century, paper presented at the seminar on the Research University as Local Citizen, University of California, San Diego, 6-7 October.

Bishop, P, Cheshire, L, Howes, M, Lawrence, G, Liebrecht, T, Loechel, B, Oliver, P, Rolfe, J \& Yee, S 2006, Engaged government: A study of governmentcommunity engagement for regional outcomes report 2: Selection of case studies, Griffith University, Brisbane, Queensland,

http:// www.griffith.edu.au/centre/cgpp/projecteg/pdf/research_report02 .pdf, accessed February 122007.

Boydell, L, Hoggett, P, Rugkåsa, J \& Cummins, A 2008, 'Intersectoral partnerships, the knowledge economy and intangible assets', Policy $\mathcal{E}$ Politics vol. 36, no. 2, pp. 209-24.

Boyer, E 1996, 'The scholarship of engagement', Journal of Public Service and Outreach, no.1, pp. 11-20.

Cooper, T 1997, 'Building an ethical community', Annual Ethics and Public Life Lecture, Queensland University of Technology, Brisbane. 
Davidson, J 2000, 'A phenomenology of fear: Merleau-Ponty and agoraphobic life-worlds', Sociology of Health and Illness, vol. 22, no. 5, pp. 640-660.

Dewey, J 1956, The child and curriculum and The school and society, University of Chicago Press, Chicago.

Dewey, J 1961, 'The school as social center', in J Boydston (ed), John Dewey: The middle works, 1899-1924, vol. 2, 1902-1903, Southern Illinois University Press, Illinois, pp. 90-91.

Garlick, S 2000, 'Engaging universities and regions: Knowledge contributions to regional economic development in Australia', EIP Report no. 00/15, DEETYA, Canberra.

Garlick, S, Benniworth, P, Puukka, J \& Vaessen, P 2006, OECD Peer Review Evaluation Report: The Twente region in the Netherlands, www.oecd.org/edu/higher/regionaldevelopment

Garlick, S 2007, 'Creative associations in special places: Enhancing the partnership role of universities in building competitive regional economies', EIP Report no. 98/4, DEETYA, Canberra.

Garlick, S \& Palmer, V 2007, 'Connecting scholarship to places: human capital, learning, enterprising and an ethical approach to communities', The Australasian Journal of University Community Engagement, vol. 2, no. 1, Spring, http://www.aucea.net.au.

Garlick, S, Taylor, M \& Plummer, P 2007, An enterprising human capital approach to regional growth: Implications for policy and the role of vocational education and training, NCVER, Adelaide, http:/ / www.ncver.edu.au/pdf.

Isaacs, P 1998, 'Social practices, medicine and the nature of medical ethics', paper presented at The Society for Health and Human Values Spring

Regional Meeting, Youngston State University, Youngston, Ohio, 17-19 April.

Palmer, V 2008, 'Uneasy terrains: mapping ethical tensions in corporate community partnerships', Third Sector Review Journal vol. 14, no. 1, pp. 51-66.

Palmer, V 2006, Narratives beyond civility: Moral protest and cooperation in ethical communities, unpublished $\mathrm{PhD}$ thesis, Queensland University of Technology, Brisbane.

Palmer, V 2001, 'Shifting focus: Putting the commun[all] back into community development', Third Sector Review Journal, vol. 7, no. 1, pp. 75-87.

Rutherford, J 2007, After identity, Lawrence \& Wishart, London.

Schwartz, S 2006, 'Higher education and the public interest', Australian Financial Review, 12 May, p. 10, http://www.afr.com/home/, accessed April 252007. 
Smith, M 2001, An ethics of place: Radical ecology, postmodernity, and social theory, State University Press, New York.

Sunderland, N \& Graham, P 1998, 'The role of academic community in higher learning: Alternatives to a drive-thru education', The Third Pacific Rim Conference Proceedings, vol. 1, Queensland University of Technology, Brisbane, http:/ / lchc.ucsd.edu/MCA/Paper/Graham/acad com.htm, accessed March 152007. 